\title{
Evaluation of Epstein-Barr virus (EBV) and human herpes virus-8 (HHV-8) in HIV-associated persistent generalized lymphadenopathy (PGL) LW Ayers*1, G Dominguez ${ }^{2}$ and K Bhatia²
}

Address: ${ }^{1}$ The Ohio State University, Columbus, Ohio, USA and ${ }^{2}$ National Cancer Institute, Bethesda, Maryland, USA

* Corresponding author

\author{
from I I th International Conference on Malignancies in AIDS and Other Acquired Immunodeficiencies (ICMAOI): Basic, Epidemiologic, and Clinical \\ Research \\ Bethesda, MD, USA. 6-7 October 2008 \\ Published: 17 June 2009 \\ Infectious Agents and Cancer 2009, 4(Suppl 2):P7 doi:10.1 186/I750-9378-4-S2-P7
}

This abstract is available from: http://www.infectagentscancer.com/content/4/S2/P7

(c) 2009 Ayers et al; licensee BioMed Central Ltd.

\section{Background}

Human immunodeficiency virus (HIV) infection is associated with persistent generalized lymphadenopathy (PGL) resulting from polyclonal $B$ cell activation with significant circulating Epstein-Barr virus (EBV). Does HHV-8 contribute to the hyperplasia when present? Unlike EBV, seroprevalence of HHV-8 in the HIV-negative U.S. population is low. Kaposi's sarcoma (KS) in HIV infected is thought to reflect "de novo" HHV-8 infection, not reactivation. Does primary HHV-8 infection present as a polyclonal B cell activation manifested as PGL such as other HHV-8 associated co-morbidities like primary effusion lymphoma and multicentric Castleman's disease? This study examines the association of HHV-8 (LANA-1) with B cells in HIV-associated PGLs.

\section{Methods}

HIV-positive serum samples from four women and 18 men (nine African-American, one African (woman) and 12 Caucasian) with available matching lymph nodes (eight axillary, eight groin, two cervical, two mandible, one supraclavicular, and one lung) constituted the study set of 22 individuals. Serum samples were examined for HHV-8 antibodies. The lymph nodes were examined histologically for HHV-8 using LANA-1 immunohistochemistry (IHC) and EBV using EBER in situ hybridization (ISH).

\section{Results}

Three sera had positive HHV-8 titers: 1). 1:1240 in a Caucasian man, age 28 , with a $1.0 \mathrm{~cm}$ hyperplastic axillary lymph node with prominent vascular proliferation and an area in the capsule with HHV-8+ endothelial cells. No LANA-1+ cells were present within the germinal centers or paracortical areas. Clinical KS was present at the time of the biopsy. 2). 1:640 in African woman, age 47, with a 2.2 $\mathrm{cm}$ axillary lymph node with giant follicular hyperplasia showing many EBER+ cells in paracortical areas and focal LANA-1 positive germinal center cells and few positive paracortical plasma cells. Pleural lymphoma developed 6 months after this biopsy. 3). 1:320 in an African/American man, age 46 , who had a $0.6 \mathrm{~cm}$ groin lymph node, both LANA-1 and EBV negative. Neither lymphoma nor KS developed during the following 7 years. Hyperplastic lymph nodes from HHV-8 seronegative patients were LANA-1 negative but EBER+ (13 of 19). EBV negative nodes were small $(0.6-0.3 \mathrm{~cm})$, groin lymph nodes.

\section{Conclusion}

PGL is associated with EBV positive cells in the paracortical areas of hyperplastic lymph nodes. HIV-positive patients with HHV-8 positive serology had large, medium, and small lymph nodes. The HHV-8 seropositive African woman's hyperplastic lymph node showed EBV(EBER) positive cells in the paracortical regions and a few HHV-8 (LANA-1)+ B cells in the germinal centers and a few positive plasma cells in the paracortical areas demonstrating 
that HHV-8 can be present in B cells. Reactivation of HHV-8 in the African woman with HIV is more likely than "de novo" infection. Significant HHV-8 associated lymph node hyperplasia in the absence of EBV appears uncommon. PGL biospecimens are available from the AIDS and Cancer Specimen Resource (ACSR) for further study.

Publish with Bio Med Central and every scientist can read your work free of charge

"BioMed Central will be the most significant development for disseminating the results of biomedical research in our lifetime. " Sir Paul Nurse, Cancer Research UK

Your research papers will be:

- available free of charge to the entire biomedical community

- peer reviewed and published immediately upon acceptance

- cited in PubMed and archived on PubMed Central

- yours - you keep the copyright 